\title{
Methylseleninic acid is a novel suppressor of aromatase expression
}

\author{
Ruijuan Gao', Lijuan Zhao ${ }^{2}$, Xichun Liu ${ }^{3}$, Brian G Rowan ${ }^{1}$, Martin Wabitsch ${ }^{4}$, Dean P Edwards ${ }^{5}$, \\ Yoshihiro Nishi ${ }^{6}$, Toshihiko Yanase ${ }^{7}$, Qun $\mathbf{Y u}^{8}$ and Yan Dong ${ }^{1,2}$ \\ ${ }^{1}$ Department of Structural and Cellular Biology, Tulane University School of Medicine, Tulane Cancer Center, New Orleans, Louisiana 70112, USA \\ ${ }^{2}$ School of Basic Medicine, Jilin University, Changchun, Jilin 130021, China \\ ${ }^{3}$ Department of Pathology and Laboratory Medicine, Tulane University School of Medicine, Tulane Cancer Center, New Orleans, Louisiana 70112, USA \\ ${ }^{4}$ Department of Pediatrics and Adolescent Medicine, Ulm University, Eythstr. 24, 89075 Ulm, Germany \\ ${ }^{5}$ Department of Molecular and Cellular Biology, Baylor College of Medicine, Houston, Texas 77030, USA \\ ${ }^{6}$ Department of Physiology, Kurume University School of Medicine, 830-0011 Fukuoka, Japan \\ ${ }^{7}$ Department of Endocrinology and Diabetes Mellitus, Fukuoka University School of Medicine, 814-0180 Fukuoka, Japan \\ ${ }^{8}$ Beijing Institute of Transfusion Medicine, Academy of Military Medical Sciences, Beijing 100850, China \\ (Correspondence should be addressed to Y Dong at Department of Structural and Cellular Biology, Tulane University School of Medicine, Tulane Cancer Center; \\ Email: ydong@tulane.edu; Q Yu; Email: yuq@nic.bmi.ac.cn)
}

\begin{abstract}
Elevated circulating estrogen levels, as a result of increased peripheral aromatization of androgens by aromatase, have been indicated to underlie the association between obesity and a higher risk of breast cancer in postmenopausal women. Although aromatase inhibitors have been used as a first-line therapy for estrogen receptor-positive breast cancer in postmenopausal women, their potential as breast cancer chemopreventive agents has been limited due to toxicities and high costs. It is therefore imperative to develop new aromatase-inhibiting/suppressing agents with lower toxicities and lower costs for breast cancer chemoprevention, especially in obese postmenopausal women. The expression of the aromatase gene, CYP19, is controlled in a tissuespecific manner by the alternate use of different promoters. In obese postmenopausal women, increased peripheral aromatase is primarily attributed to the activity of the
\end{abstract}

glucocorticoid-stimulated promoter, PI.4, and the cAMPstimulated promoter, PII. In the present study, we show that methylseleninic acid (MSA), a second-generation selenium compound, can effectively suppress aromatase activation by dexamethasone, a synthetic glucocorticoid, and forskolin, a specific activator of adenylate cyclase. Unlike the action of aromatase inhibitors, MSA suppression of aromatase activation is not mediated via direct inhibition of aromatase enzymatic activity. Rather, it is attributable to a marked downregulation of promoters PI.4- and PII-specific aromatase mRNA expression, and thereby a reduction of aromatase protein. Considering the low-cost and low-toxicity nature of MSA, our findings provide a strong rationale for the further development of MSA as a breast cancer chemopreventive agent for obese postmenopausal women.

Journal of Endocrinology (2012) 212, 199-205

\section{Introduction}

Cytochrome P450 aromatase (CYP19) is the key enzyme for estrogen biosynthesis, and is responsible for converting androgens to estrogens (Simpson et al. 1994). In premenopausal women, aromatase is predominantly expressed in ovarian granulosa cells or placental syncytiotrophoblasts during pregnancy (Simpson et al. 1994). In postmenopausal women, after the ovaries have ceased to produce estrogens, adipose tissue becomes the principal site of estrogen biosynthesis (Simpson et al. 1994). Estrogen is known to play a critical role in breast cancer development and progression (Evans 1988), making aromatase an important target for breast cancer prevention and therapy.

The human aromatase gene has several promoters. Although the aromatase-coding region and protein are identical in all tissues that express aromatase, the promoter usage for transcription is somewhat tissue-specific (Bulun et al. 2005). The distal promoter I.4, which is located $\sim 70 \mathrm{~kb}$ upstream of the translation start site, is the major promoter used in skin and adipose stromal cells for aromatase expression. Promoter I.4 can be activated by glucocorticoid (Mahendroo et al. 1993). The proximal promoter PII, just upstream of the translation start site, is used in premenopausal ovarian granulosa cells, breast cancer cells, and cancer adjacent breast adipose stromal cells (Agarwal et al. 1996). PII can be activated by FSH and LH in ovarian tissue, and cytokines such as prostaglandin E2 in breast tumors, through the cAMP-protein kinase A signaling pathway (Simpson et al. 1994, Zhao et al. 1996a). It has also been reported that altered adipokine milieu associated with obesity, e.g. elevated leptin level, can activate strong PII-induced aromatase expression in the peripheral 
adipose tissue of obese women, resulting in elevated peripheral aromatization of androgens and increased circulating estrogen levels (Geisler et al. 2007, Maccio et al. 2009, Hursting 2011). This may underlie the association between obesity and increased risk of breast cancer in postmenopausal women (Brown et al. 2009, Brown \& Simpson 2010).

Aromatase inhibitors are a first-line therapy for estrogen receptor-positive breast cancer in postmenopausal women. However, due to systemic suppression of estrogen biosynthesis, treatment with aromatase inhibitors often leads to side effects associated with estrogen depletion, including arthralgia, bone loss, and bone fracture, as well as possible cardiovascular and neurocognitive defects (Thurlimann et al. 2005, Buzdar et al. 2006, Coombes et al. 2007). As a result of these adverse effects and also the high costs of aromatase inhibitors, $23-30 \%$ of patients could not complete aromatase inhibitor therapy (Hershman et al. 2010, Sedjo \& Devine 2011). With this high rate of nonadherence in patients with life-threatening cancer, it is reasonable to believe that patient acceptance of aromatase inhibitors as a breast cancer chemopreventive option could be limited. Therefore, it is imperative to develop new agents with lower toxicities and lower costs for breast cancer prevention.

Low serum and toenail selenium levels (a measure of long-term selenium intake) are associated with an increased risk of breast cancer (Charalabopoulos et al. 2006, Suzana et al. 2009, Kotsopoulos et al. 2010). Selenium supplementation has been demonstrated by numerous preclinical studies to effectively inhibit the development of breast cancer (Ip 1998, Ip et al. 2002), while having a low toxicity profile (Reid et al. 2004). The anticancer efficacy depends on the form and dosage of selenium administered (Ip 1998, Ip et al. 2000, Li et al. 2004, 2008, Wang et al. 2009). Methylseleninic acid (MSA) is a potent second-generation selenium compound. It has very different biological and pharmacological activity than selenomethionine, the form of selenium used in the selenium and vitamin E chemoprevention trial (Ip 1998, Ip et al. 2000, Li et al. 2008, Lippman et al. 2009, Ohta et al. 2009, Wang et al. 2009). In the present study, we characterized the effect of MSA on estrogen biosynthesis that has never been investigated before. We focused on the effect on promoters PI.4- and PII-driven aromatase expression because of the important role of these two promoters in regulating estrogen level in obese postmenopausal women. The long-term objective of the present study is to develop MSA as a low-cost, low-toxicity breast cancer chemopreventive agent for obese postmenopausal women.

\section{Materials and Methods}

\section{Cell culture and reagents}

The KGN human ovarian granulosa tumor cell line was established from a postmenopausal patient with invasive ovarian granulosa cell carcinoma (Nishi et al. 2001). KGN cells are undifferentiated, and maintain physiological characteristics of ovarian cells, including the expression of functional FSH receptor, relatively high aromatase activity, and the expression of estrogen receptor- $\beta$ as the predominant isoform of estrogen receptor (Nishi et al. 2001, Chu et al. 2004). The cells were regularly cultured in DMEM/F12 medium supplemented with $10 \%$ fetal bovine serum (FBS) and $1 \%$ penicillin/streptomycin. The human preadipocyte cell strain, SGBS, was derived from an adipose depot of an infant with Simpson-Golabi-Behmel syndrome (Wabitsch et al. 2001). SGBS cells were routinely cultured in growth medium comprising DMEM/F12 medium supplemented with $10 \%$ FBS, $1 \%$ penicillin/streptomycin, $33 \mu \mathrm{M}$ biotin, and $17 \mu \mathrm{M}$ pantothenic acid. All the SGBS cells used in this study were in passage 30 to passage 35 . The cells were switched to hormone-deprived medium (phenol red-free medium containing charcoal-stripped-FBS) for analysis of aromatase activity, protein, and mRNA. MSA was obtained from PharmaSe (Lubbock, TX, USA). ${ }^{3} \mathrm{H}$-Androst-4-ene3,17-dione was from PerkinElmer (Waltham, MA, USA). Dexamethasone (Dex), forskolin (FSK), and other reagents were purchased from Sigma-Aldrich.

\section{Establishment of aromatase-overexpressing MCF-7arom cells}

The aromatase cDNA with the $129 \mathrm{bp} 5^{\prime}$-UTR sequence was PCR amplified from the CYP19A1-coding plasmid (SC107980, OriGene, Rockville, MS, USA) and subcloned into pcDNA3.1/Zeo $(+)$ between the HindIII and XbaI sites. The resulting pcDNA3.1-aromatase construct was transfected to MCF-7 cells and selected with $100 \mu \mathrm{g} / \mathrm{ml}$ Zeocin for 3 months to generate stable aromatase-overexpressing MCF-7 cells, MCF-7arom. MCF-7arom cells were regularly cultured in DMEM medium containing 5\% FBS, $1 \%$ penicillin/streptomycin, and $50 \mu \mathrm{g} / \mathrm{ml}$ Zeocin.

\section{Aromatase activity assay}

Aromatase activity was determined by using the tritiated water release assay that measures the amount of ${ }^{3} \mathrm{H}_{2} \mathrm{O}$ formed during the conversion of ${ }^{3} \mathrm{H}$-androstenedione to estrone by aromatase (Silva et al. 1989). SGBS cells were seeded to six-well plates $\left(2 \times 10^{4}\right.$ cells/well) in hormone-deprived medium and allowed to attach overnight. The cells were treated with $250 \mathrm{nM}$ Dex in the presence or absence of MSA for 6 or $16 \mathrm{~h}$, and then washed twice with PBS before being incubated in fresh hormone-deprived medium containing $6 \mathrm{nM}{ }^{3} \mathrm{H}$-androst-4ene-3,17-dione for an additional $4 \mathrm{~h}$. Following incubation, the medium was removed and extracted with two volumes of chloroform. The samples were then centrifuged at $2000 \mathrm{~g}$ for $10 \mathrm{~min}$, and the aqueous upper layer was mixed with $2 \%$ charcoal followed by an additional centrifugation at $12000 \mathrm{~g}$ for $10 \mathrm{~min}$ to remove any trace amount of unreacted substrate. A $500 \mu \mathrm{l}$ aliquot of the supernatant for each sample was subsequently subjected to liquid scintillation counting.

For KGN cells, the aromatase activity assay was performed the same way as for SGBS cells except that $25 \mu \mathrm{M}$ FSK were 
used to replace Dex to induce aromatase activity. For determining the direct effect of MSA on aromatase enzymatic activity in SGBS and KGN cells, MSA was not added to the Dex- or FSK-containing medium, but was present during the last $4 \mathrm{~h}$ of incubation together with ${ }^{3} \mathrm{H}$-androst4-ene-3,17-dione.

\section{Western blot analysis}

KGN cells were seeded to hormone-deprived medium and cultured overnight. The cells were treated with FSK in the presence or absence of MSA for 6 or $16 \mathrm{~h}$. Following treatment, the cells were washed twice with ice-cold PBS, and scraped in lysis buffer (Cell Signaling, Danvers, MA, USA). SDS-PAGE and western blotting procedures were done as described before (Liu et al. 2010). The mouse aromatase monoclonal antibody, 677/H7, was developed as described (Sasano et al. 2005), and the GAPDH antibody was obtained from Millipore (Billerica, MA, USA).

\section{Aromatase total $m R N A$ quantification}

SGBS and KGN cells were seeded to hormone-deprived medium and cultured overnight before treatment. The cells were treated with MSA for $3 \mathrm{~h}$. RNA extraction and realtime RT-PCR procedures were done as previously described (Dong et al. 2004). The primer-probe sets for aromatase (Hs00903409-m1) and $\beta$-actin (Hs99999903-m1) were from Applied Biosystems (Carlsbad, CA, USA).

\section{Promoter-specific aromatase $m R N A$ quantification}

Promoter-specific aromatase PCR amplifications were performed with the use of the Sybr Green Supermix (Bio-Rad). The primer sequences specific to PI.4 (sense, GTGACCAACTGGAGCCTG; antisense, CAGGAATCTGCCGTGGGAGA) and PII (sense, GCAACAGGAGCTATAGAT; antisense, CAGGAATCTGCCGTGGGAGA) were as previously described (McInnes et al. 2008). The data were normalized to $\beta$-actin levels.

\section{Statistical analysis}

Mean activities were calculated from at least three independent experiments done in triplicate. The Student's two-tailed $t$-test was used to determine the significant differences between two groups. $P<0 \cdot 05$ is considered statistically significant.

\section{Results}

\section{MSA inhibits aromatase activation}

As described in the Introduction, promoters PI.4 and PII can be activated by glucocorticoid and CAMP-protein kinase A signaling respectively. We first assessed the effect of MSA on aromatase activity induced by glucocorticoid and cAMPprotein kinase A. SGBS and KGN cells were chosen as the cell models for our study because their aromatase expression is driven mainly by promoter PI.4 or PII respectively (Ghosh et al. 2008, McInnes et al. 2008). Consistent with previous reports (McInnes et al. 2008, Ohno et al. 2009), the basal activity of aromatase was almost undetectable in both cell models, and the activity was induced respectively by Dex, a synthetic glucocorticoid, or FSK, a highly specific activator of adenylate cyclase (Fig. 1). Treatment of SGBS cells with MSA led to a dose-dependent inhibition of Dex-induced aromatase activation (Fig. 1A). The inhibitory effect of MSA on FSK induction of aromatase appears to be even more robust (Fig. 1B). A more than 60\% inhibition was already evident with $0.6 \mu \mathrm{M}$ MSA (Fig. 1B).

MSA inhibition of aromatase activation is not mediated at the enzymatic level

Aromatase inhibitors suppress aromatase activity through disrupting the binding of the substrates to aromatase (Chen et al. 2007). In order to determine whether the same mechanism underlies MSA inhibition of aromatase activation, we assessed the direct effect of MSA on the enzymatic activity of aromatase. The experiment was done by adding MSA to the culture at the same time as ${ }^{3} \mathrm{H}$-androstenedione so that MSA was not present when aromatase expression was induced
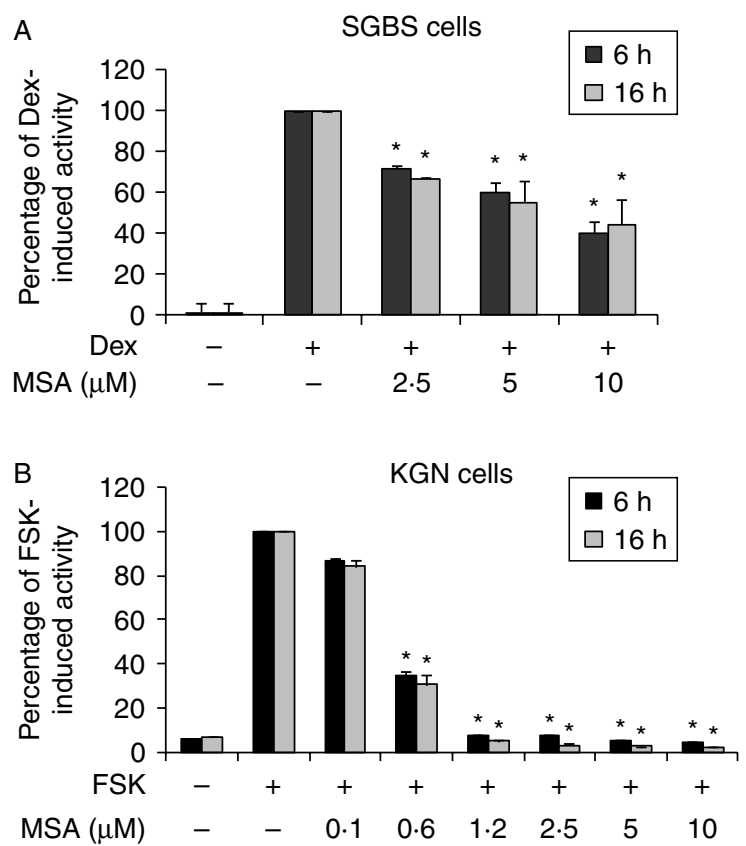

Figure 1 Aromatase activity in (A) SGBS and (B) KGN cells in response to MSA treatment. Cells were treated with or without inducers in the presence or absence of MSA in phenol red-free medium for 6 or $16 \mathrm{~h}$. The inducers and MSA were then removed, and cells were incubated with ${ }^{3} \mathrm{H}$-androstenedione for an additional $4 \mathrm{~h}$. ${ }^{*} P<0 \cdot 05$ compared to inducer-treated sample. 

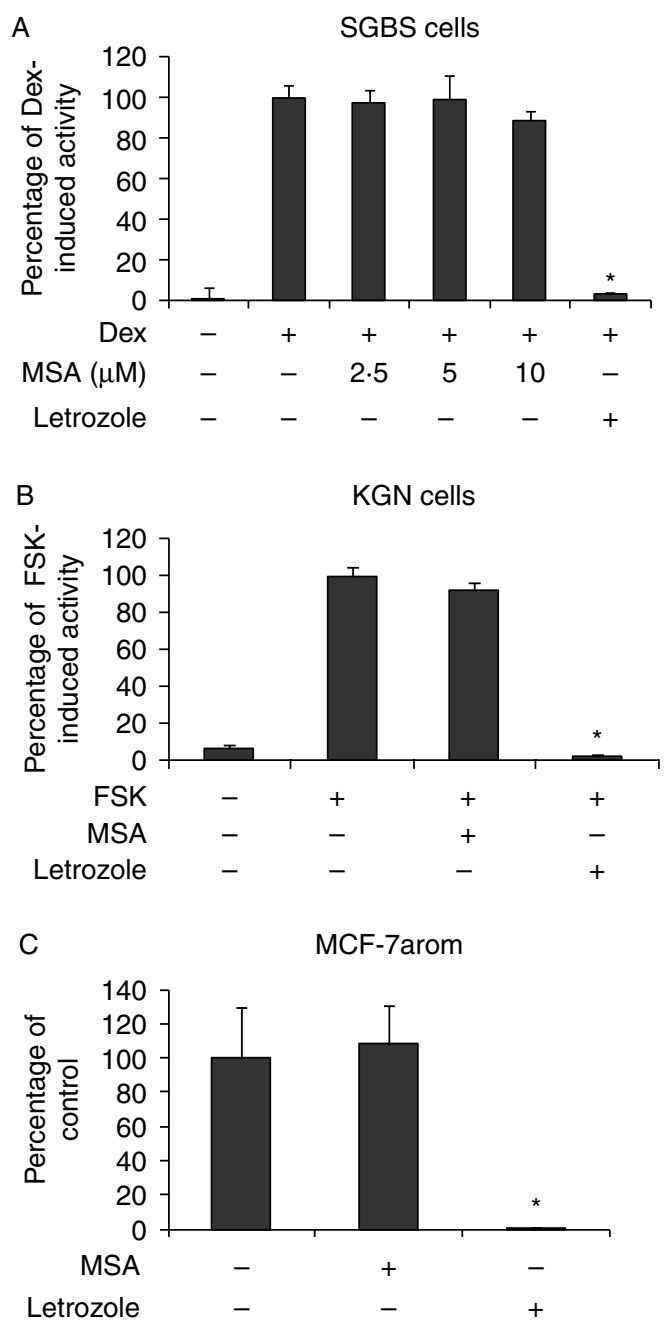

Figure 2 Direct effect of MSA on aromatase enzymatic activity in (A) SGBS, (B) KGN, and (C) aromatase-transfected MCF-7arom cells. Cells were treated with inducers in phenol red-free medium for $16 \mathrm{~h}$. Inducers were then removed, and cells were incubated with ${ }^{3} \mathrm{H}$-androstenedione in the presence or absence of MSA or letrozole for an additional $4 \mathrm{~h} .{ }^{*} P<0 \cdot 05$ compared to inducer-treated sample.

by Dex or FSK. We used the aromatase inhibitor letrozole as the positive control. The data, as presented in Fig. $2 \mathrm{~A}$ and B, showed that, in both SGBS and KGN cells, while letrozole almost completely abolished the activity of aromatase, no significant change of aromatase activity was detected after MSA treatment. We also determined the response of an aromatase-overexpressing stable transfectant, MCF-7arom, to MSA treatment. The expression of aromatase in MCF-7arom cells is driven by a constitutive promoter. Consistently, we did not observe modulation of aromatase activity by MSA in these cells (Fig. 2C). The data were apparently different from that obtained when MSA was added to the culture together with the aromatase expression inducers (Fig. 1), indicating that the effect of MSA on aromatase is not mediated through affecting aromatase enzymatic activity.
MSA downregulates PI.4- and PII-mediated aromatase expression

To unravel the mechanism by which MSA inhibits aromatase activation, we assessed MSA modulation of aromatase protein. As shown in Fig. 3A, $0.6 \mu \mathrm{M}$ MSA inhibited FSK-induced aromatase protein by more than $50 \%$, and $2.5 \mu \mathrm{M}$ MSA totally blocked the induction. We also examined the effect of MSA on Dex-induced aromatase protein expression in SGBS cells. However, the low level of aromatase expression in SGBS cells, even after Dex induction, was under the detection limit of aromatase western blot analysis. We next characterized the effect of MSA on the level of total aromatase mRNA by real-time RT-PCR using primers recognizing all aromatase transcripts. As shown in Fig. 3B and C, MSA significantly suppressed Dex and FSK induction of aromatase mRNA, and the effect on FSK-induced expression was even more pronounced. In order to confirm that the decrease in total aromatase mRNA was due to suppression of transcription from promoter PI.4 or PII, we repeated the real-time RT-PCR analysis using primers specific to PI.4 or PII. The results, as shown in Fig. 4, are in great concordance with that presented in Fig. 3B and C. Taken together, the data indicated that MSA suppressed aromatase activation through downregulating promoter PI.4- and PII-driven aromatase mRNA expression.

\section{Discussion}

Elevated circulating estrogen levels, as a result of increased peripheral aromatization of androgens, have been indicated to underlie the association between obesity and a higher risk of breast cancer in postmenopausal women (Brown et al. 2009,

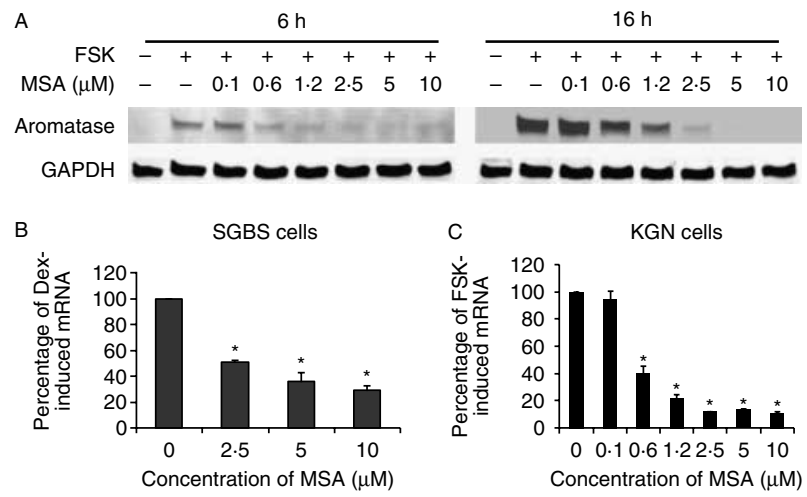

Figure 3 Effect of MSA on aromatase protein expression in KGN cells (A) and aromatase mRNA expression in SGBS (B) and KGN cells $(C)$. Cells were treated with inducers in the presence or absence of MSA in phenol red-free medium containing charcoalstripped FBS for 6 or $16 \mathrm{~h}$ for protein analysis and for $3 \mathrm{~h}$ for aromatase mRNA expression. ${ }^{*} P<0.05$ compared to inducertreated sample. 

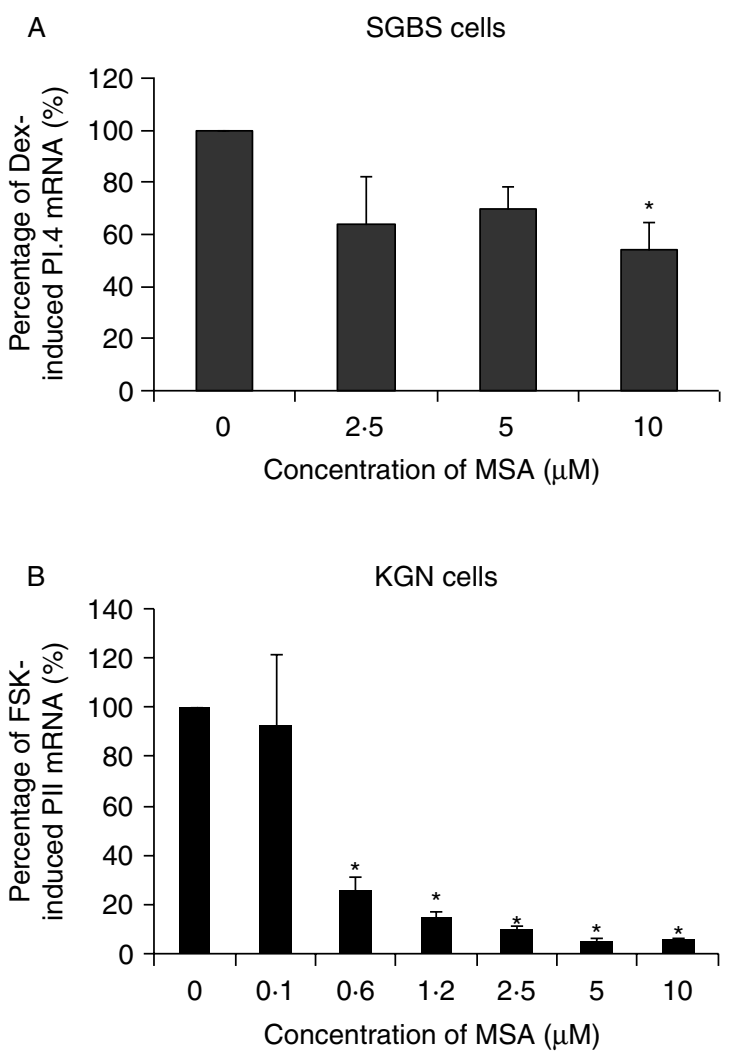

Figure 4 MSA effect on promoter (A) PI.4- and (B) PII-specific aromatase expression in SGBS and KGN cells respectively. Cells were treated with inducers in the presence or absence of MSA in phenol red-free medium containing charcoal-stripped FBS for $3 \mathrm{~h}$ $* P<0 \cdot 05$ compared to inducer-treated sample.

Brown \& Simpson 2010). In the present study, we showed that both PI.4- and PII-driven aromatase transcription can be efficiently suppressed by MSA, leading to a marked downregulation of aromatase mRNA, protein, and thereby activity. Considering the low-cost and low-toxicity nature of MSA, the data provide a strong rationale for the further development of MSA as a breast cancer chemopreventive agent for obese postmenopausal women.

Our data on MSA suppression of PII- and PI.4-driven aromatase expression also suggest a role of MSA in reducing breast intratumoral estrogen level. In postmenopausal breast cancer patients, tumor concentration of estrogens has been reported to be $\sim 10$ times the concentration in plasma (van Landeghem et al. 1985, Bulun et al. 1993, Agarwal et al. 1996, Miller et al. 1997). This is attributable to the heterotypic interaction between breast tumor cells and tumor adjacent adipose stromal cells (Bulun et al. 2005). In response to estrogen stimulation, breast tumor cells secrete large amounts of cytokines, such as tumor necrosis factor $\alpha$ and interleukin 11 , to inhibit adipogenic differentiation of adjacent stromal cells (Crichton et al. 1996, Meng et al. 2001). This leads to an upregulated PII promoter activity (Irahara et al. 2006) and thereby an elevated local aromatase expression and estrogen level (Meng et al. 2001), thus creating a localized, growthstimulatory environment for tumor cells. In addition, aromatase expression has also been detected in breast tumor cells, although at a much lower level compared to the adipose stromal cells (Miki et al. 2007). Promoter PII is also a main promoter driving the expression of aromatase in breast tumor cells (Agarwal et al. 1996). Therefore, reducing intratumoral production of estrogen may represent an additional novel mechanism of MSA anticancer action.

In fact, we have sought to study the effect of MSA on aromatase expression in breast cancer cell lines. However, none of the breast cancer cell lines that we have tested, including MCF-7, T47D, and MDA-MB-468, have detectable aromatase expression even after inducer treatment. Whether cultured breast cancer cell lines express a detectable amount of aromatase is still debatable. While some groups were able to detect aromatase expression in cell lines such as MCF-7, T47D, and MDA-MB-468 (Kijima et al. 2006, Miki et al. 2007, Ciolino et al. 2011), others could not (Sanderson et al. 2001, Heneweer et al. 2005). Nevertheless, the data that we obtained from KGN cells should be applicable to breast tumor cells as PII-mediated expression is regulated mainly by the cAMP-protein kinase A pathway in both cell types (Zhao et al. 1996a, Ghosh et al. 2008).

A number of transcription factors have been implicated in PII regulation, including LRH-1, CREB, CRTC2, ATF2, SF-1, C/EBPs, Jun, and several orphan nuclear receptors (Zhou et al. 2001, Clyne et al. 2002, Yang et al. 2002, Sofi et al. 2003, Ghosh et al. 2008, Kijima et al. 2008, Brown et al. 2009). PI.4 is a TATA-less promoter that contains a glucocorticoid response element, Sp1-binding site, and an interferon- $\gamma$ activation site element (Zhao et al. 1996b). The JAK/STAT signaling pathway has been reported to be involved in PI.4 regulation (Zhao et al. 1995). MSA has been shown to alter the expression levels of a number of proteins in stromal cells, including cAMP-responsive element-binding protein 6 (CREB6) (Jiang et al. 1999, Tsavachidou et al. 2009, Zhang et al. 2010). We are currently investigating the effect of MSA on signal transduction from the cAMP-protein kinase A and glucocorticoid receptor/JAK/STAT pathways to elucidate the mechanisms by which MSA inhibits aromatase expression.

\section{Declaration of interest}

The authors declare that there is no conflict of interest that could be perceived as prejudicing the impartiality of the research reported.

\section{Funding}

This work was supported by the National Cancer Institute (grant number K01CA114252), American Cancer Society (grant number RSG-07-21801-TBE), the Mary Kay Foundation (grant number 019-11), Louisiana Cancer Research Consortium (Start-up Fund), and the Tulane Cancer Center (developmental funds). 


\section{Author contribution statement}

Y D, R G, L Z, B G R, and Q Y designed the research; R G and X L conducted the study; R G, B G R, Q Y, and Y D wrote the paper; M W supplied SGBS cells; D P E supplied the aromatase antibody; Y N and T Y supplied KGN cells; Y D and Y Q had primary responsibility for the final content.

\section{Acknowledgements}

We thank Dr Yanfen Hu at the University of Texas Health Science Center at San Antonio for sharing KGN cells.

\section{References}

Agarwal VR, Bulun SE, Leitch M, Rohrich R \& Simpson ER 1996 Use of alternative promoters to express the aromatase cytochrome P450 (CYP19) gene in breast adipose tissues of cancer-free and breast cancer patients. Journal of Clinical Endocrinology and Metabolism 81 3843-3849. (doi:10.1210/ jc.81.11.3843)

Brown KA \& Simpson ER 2010 Obesity and breast cancer: progress to understanding the relationship. Cancer Research 70 4-7. (doi:10.1158/00085472.CAN-09-2257)

Brown KA, McInnes KJ, Hunger NI, Oakhill JS, Steinberg GR \& Simpson ER 2009 Subcellular localization of cyclic AMP-responsive element binding protein-regulated transcription coactivator 2 provides a link between obesity and breast cancer in postmenopausal women. Cancer Research 69 5392-5399. (doi:10.1158/0008-5472.CAN-09-0108)

Bulun SE, Price TM, Aitken J, Mahendroo MS \& Simpson ER 1993 A link between breast cancer and local estrogen biosynthesis suggested by quantification of breast adipose tissue aromatase cytochrome $\mathrm{P} 450$ transcripts using competitive polymerase chain reaction after reverse transcription. Journal of Clinical Endocrinology and Metabolism 77 1622-1628. (doi:10.1210/jc.77.6.1622)

Bulun SE, Lin Z, Imir G, Amin S, Demura M, Yilmaz B, Martin R, Utsunomiya H, Thung S, Gurates B et al. 2005 Regulation of aromatase expression in estrogen-responsive breast and uterine disease: from bench to treatment. Pharmacological Reviews 57 359-383. (doi:10.1124/pr.57.3.6)

Buzdar A, Howell A, Cuzick J, Wale C, Distler W, Hoctin-Boes G, Houghton J, Locker GY \& Nabholtz JM 2006 Comprehensive side-effect profile of anastrozole and tamoxifen as adjuvant treatment for early-stage breast cancer: long-term safety analysis of the ATAC trial. Lancet Oncology 7 633-643. (doi:10.1016/S1470-2045(06)70767-7)

Charalabopoulos K, Kotsalos A, Batistatou A, Charalabopoulos A, Vezyraki P, Peschos D, Kalfakakou V \& Evangelou A 2006 Selenium in serum and neoplastic tissue in breast cancer: correlation with CEA. British Journal of Cancer 95 674-676. (doi:10.1038/sj.bjc.6603292)

Chen S, Masri S, Hong Y, Wang X, Phung S, Yuan YC \& Wu X 2007 New experimental models for aromatase inhibitor resistance. Journal of Steroid Biochemistry and Molecular Biology 106 8-15. (doi:10.1016/j.jsbmb. 2007.05.020)

Chu S, Nishi Y, Yanase T, Nawata H \& Fuller PJ 2004 Transrepression of estrogen receptor beta signaling by nuclear factor-kappab in ovarian granulosa cells. Molecular Endocrinology 18 1919-1928. (doi:10.1210/me. 2004-0021)

Ciolino HP, Dai Z \& Nair V 2011 Retinol inhibits aromatase activity and expression in vitro. Journal of Nutritional Biochemistry 22 522-526. (doi:10. 1016/j.jnutbio.2010.04.004)

Clyne CD, Speed CJ, Zhou J \& Simpson ER 2002 Liver receptor homologue1 (LRH-1) regulates expression of aromatase in preadipocytes. Journal of Biological Chemistry 277 20591-20597. (doi:10.1074/jbc.M201117200)

Coombes RC, Kilburn LS, Snowdon CF, Paridaens R, Coleman RE, Jones SE, Jassem J, van de Velde CJ, Delozier T, Alvarez I et al. 2007 Survival and safety of exemestane versus tamoxifen after 2-3 years' tamoxifen treatment (Intergroup Exemestane Study): a randomised controlled trial. Lancet 369 559-570. (doi:10.1016/S0140-6736(07)60200-1)

Crichton MB, Nichols JE, Zhao Y, Bulun SE \& Simpson ER 1996 Expression of transcripts of interleukin- 6 and related cytokines by human breast tumors, breast cancer cells, and adipose stromal cells. Molecular and Cellular Endocrinology 118 215-220. (doi:10.1016/0303-7207(96)03761-6)

Dong Y, Lee SO, Zhang H, Marshall J, Gao AC \& Ip C 2004 Prostate specific antigen expression is down-regulated by selenium through disruption of androgen receptor signaling. Cancer Research 64 19-22. (doi:10.1158/00085472.CAN-03-2789)

Evans RM 1988 The steroid and thyroid hormone receptor superfamily. Science 240 889-895. (doi:10.1126/science.3283939)

Geisler J, Haynes B, Ekse D, Dowsett M \& Lonning PE 2007 Total body aromatization in postmenopausal breast cancer patients is strongly correlated to plasma leptin levels. Journal of Steroid Biochemistry and Molecular Biology 104 27-34. (doi:10.1016/j.jsbmb.2006.09.040)

Ghosh S, Lu Y \& Hu Y 2008 A role of CREB in BRCA1 constitutive promoter activity and aromatase basal expression. International Journal of Biomedical Science 4 260-265.

Heneweer M, Muusse M, Dingemans M, de Jong PC, van den Berg M \& Sanderson JT 2005 Co-culture of primary human mammary fibroblasts and MCF-7 cells as an in vitro breast cancer model. Toxicological Sciences $\mathbf{8 3}$ 257-263. (doi:10.1093/toxsci/kfi025)

Hershman DL, Kushi LH, Shao T, Buono D, Kershenbaum A, Tsai WY, Fehrenbacher L, Lin GS, Miles S \& Neugut AI 2010 Early discontinuation and nonadherence to adjuvant hormonal therapy in a cohort of 8,769 early-stage breast cancer patients. Journal of Clinical Oncology 28 4120-4128. (doi:10.1200/JCO.2009.25.9655)

Hursting SD 2011 Inflammatory talk: linking obesity, NF-kappaB, and aromatase. Cancer Prevention Research 4 285-287. (doi:10.1158/1940-6207. CAPR-11-0056)

Ip C 1998 Lessons from basic research in selenium and cancer prevention. Journal of Nutrition 128 1845-1854.

Ip C, Thompson HJ, Zhu Z \& Ganther HE 2000 In vitro and in vivo studies of methylseleninic acid: evidence that a monomethylated selenium metabolite is critical for cancer chemoprevention. Cancer Research 60 2882-2886.

Ip C, Dong Y \& Ganther HE 2002 New concepts in selenium chemoprevention. Cancer Metastasis Reviews 21 281-289. (doi:10.1023/A:1021263027659)

Irahara N, Miyoshi Y, Taguchi T, Tamaki Y \& Noguchi S 2006 Quantitative analysis of aromatase mRNA expression derived from various promoters (I.4, I.3, PII and I.7) and its association with expression of TNF-alpha, IL-6 and COX-2 mRNAs in human breast cancer. International Journal of Cancer 118 1915-1921. (doi:10.1002/ijc.21562)

Jiang C, Jiang W, Ip C, Ganther H \& Lu J 1999 Selenium-induced inhibition of angiogenesis in mammary cancer at chemopreventive levels of intake. Molecular Carcinogenesis 26 213-225. (doi:10.1002/(SICI)10982744(199912)26:4<213::AID-MC1 > 3.0.CO;2-Z)

Kijima I, Phung S, Hur G, Kwok SL \& Chen S 2006 Grape seed extract is an aromatase inhibitor and a suppressor of aromatase expression. Cancer Research 66 5960-5967. (doi:10.1158/0008-5472.CAN-06-0053)

Kijima I, Ye J, Glackin C \& Chen S 2008 CCAAT/enhancer binding protein delta up-regulates aromatase promoters I.3/II in breast cancer epithelial cells. Cancer Research 68 4455-4464. (doi:10.1158/0008-5472.CAN-07-3249)

Kotsopoulos J, Chen Z, Vallis KA, Poll A, Ghadirian P, Kennedy G, Ainsworth P \& Narod SA 2010 Toenail selenium status and DNA repair capacity among female BRCA1 mutation carriers. Cancer Causes \& Control 21 679-687. (doi:10.1007/s10552-009-9495-8)

van Landeghem AA, Poortman J, Nabuurs M \& Thijssen JH 1985 Endogenous concentration and subcellular distribution of estrogens in normal and malignant human breast tissue. Cancer Research 45 2900-2906.

Li H, Stampfer MJ, Giovannucci EL, Morris JS, Willett WC, Gaziano JM \& Ma J 2004 A prospective study of plasma selenium levels and prostate cancer risk. Journal of the National Cancer Institute 96 696-703. (doi:10.1093/jnci/djh125)

Li GX, Lee HJ, Wang Z, Hu H, Liao JD, Watts JC, Combs GF Jr \& Lu J 2008 Superior in vivo inhibitory efficacy of methylseleninic acid against human prostate cancer over selenomethionine or selenite. Carcinogenesis 29 1005-1012. (doi:10.1093/carcin/bgn007) 
Lippman SM, Klein EA, Goodman PJ, Lucia MS, Thompson IM, Ford LG, Parnes HL, Minasian LM, Gaziano JM, Hartline JA et al. 2009 Effect of selenium and vitamin $\mathrm{E}$ on risk of prostate cancer and other cancers: the Selenium and Vitamin E Cancer Prevention Trial (SELECT). Journal of the American Medical Association 301 39-51. (doi:10.1001/jama.2008.864)

Liu S, Qi Y, Ge Y, Duplessis T, Rowan BG, Ip C, Cheng H, Rennie PS, Horikawa I, Lustig AJ et al. 2010 Telomerase as an important target of androgen signaling blockade for prostate cancer treatment. Molecular Cancer Therapeutics 9 2016-2025. (doi:10.1158/1535-7163.MCT-09-0924)

Maccio A, Madeddu C \& Mantovani G 2009 Adipose tissue as target organ in the treatment of hormone-dependent breast cancer: new therapeutic perspectives. Obesity Reviews 10 660-670. (doi:10.1111/j.1467-789X. 2009.00592.x)

Mahendroo MS, Mendelson CR \& Simpson ER 1993 Tissue-specific and hormonally controlled alternative promoters regulate aromatase cytochrome P450 gene expression in human adipose tissue. Journal of Biological Chemistry 268 19463-19470.

McInnes KJ, Brown KA, Knower KC, Chand AL, Clyne CD \& Simpson ER 2008 Characterisation of aromatase expression in the human adipocyte cell line SGBS. Breast Cancer Research and Treatment 112 429-435. (doi:10.1007/ s10549-007-9883-2)

Meng L, Zhou J, Sasano H, Suzuki T, Zeitoun KM \& Bulun SE 2001 Tumor necrosis factor alpha and interleukin 11 secreted by malignant breast epithelial cells inhibit adipocyte differentiation by selectively downregulating CCAAT/enhancer binding protein alpha and peroxisome proliferator-activated receptor gamma: mechanism of desmoplastic reaction. Cancer Research 61 2250-2255.

Miki Y, Suzuki T, Tazawa C, Yamaguchi Y, Kitada K, Honma S, Moriya T, Hirakawa H, Evans DB, Hayashi S et al. 2007 Aromatase localization in human breast cancer tissues: possible interactions between intratumoral stromal and parenchymal cells. Cancer Research 67 3945-3954. (doi:10. 1158/0008-5472.CAN-06-3105)

Miller WR, Mullen P, Sourdaine P, Watson C, Dixon JM \& Telford J 1997 Regulation of aromatase activity within the breast. Journal of Steroid Biochemistry and Molecular Biology 61 193-202.

Nishi Y, Yanase T, Mu Y, Oba K, Ichino I, Saito M, Nomura M, Mukasa C, Okabe T, Goto K et al. 2001 Establishment and characterization of a steroidogenic human granulosa-like tumor cell line, KGN, that expresses functional follicle-stimulating hormone receptor. Endocrinology 142 437-445. (doi:10.1210/en.142.1.437)

Ohno S, Yukinawa F, Noda M \& Nakajin S 2009 Mono-(2-ethylhexyl) phthalate induces NR4A subfamily and GIOT-1 gene expression, and suppresses CYP19 expression in human granulosa-like tumor cell line KGN. Toxicology Letters 191 353-359. (doi:10.1016/j.toxlet.2009.10.004)

Ohta Y, Kobayashi Y, Konishi S \& Hirano S 2009 Speciation analysis of selenium metabolites in urine and breath by HPLC- and GC-inductively coupled plasma-MS after administration of selenomethionine and methylselenocysteine to rats. Chemical Research in Toxicology 22 1795-1801. (doi:10.1021/tx900202m)

Reid ME, Stratton MS, Lillico AJ, Fakih M, Natarajan R, Clark LC \& Marshall JR 2004 A report of high-dose selenium supplementation: response and toxicities. Journal of Trace Elements in Medicine and Biology 18 69-74. (doi:10.1016/j.jtemb.2004.03.004)

Sanderson JT, Letcher RJ, Heneweer M, Giesy JP \& van den Berg M 2001 Effects of chloro-s-triazine herbicides and metabolites on aromatase activity in various human cell lines and on vitellogenin production in male carp hepatocytes. Environmental Health Perspectives 109 1027-1031. (doi:10. 1289/ehp.011091027)

Sasano H, Anderson TJ, Silverberg SG, Santen RJ, Conway M, Edwards DP, Krause A, Bhatnagar AS, Evans DB \& Miller WR 2005 The validation of new aromatase monoclonal antibodies for immunohistochemistry - a correlation with biochemical activities in 46 cases of breast cancer. Journal of Steroid Biochemistry and Molecular Biology 95 35-39. (doi:10.1016/j.jsbmb. 2005.04.027)

Sedjo RL \& Devine S 2011 Predictors of non-adherence to aromatase inhibitors among commercially insured women with breast cancer. Breast Cancer Research and Treatment 125 191-200. (doi:10.1007/s10549-010-0952-6)
Silva MC, Rowlands MG, Dowsett M, Gusterson B, McKinna JA, Fryatt I \& Coombes RC 1989 Intratumoral aromatase as a prognostic factor in human breast carcinoma. Cancer Research 49 2588-2591.

Simpson ER, Mahendroo MS, Means GD, Kilgore MW, Hinshelwood MM, Graham-Lorence S, Amarneh B, Ito Y, Fisher CR \& Michael MD 1994 Aromatase cytochrome P450, the enzyme responsible for estrogen biosynthesis. Endocrine Reviews 15 342-355.

Sofi M, Young MJ, Papamakarios T, Simpson ER \& Clyne CD 2003 Role of CRE-binding protein (CREB) in aromatase expression in breast adipose. Breast Cancer Research and Treatment 79 399-407. (doi:10.1023/ A:1024038632570)

Suzana S, Cham BG, Ahmad RG, Mohd RR, Fairulnizal MN, Normah H \& Fatimah A 2009 Relationship between selenium and breast cancer: a casecontrol study in the Klang Valley. Singapore Medical Journal 50 265-269.

Thurlimann B, Keshaviah A, Coates AS, Mouridsen H, Mauriac L, Forbes JF, Paridaens R, Castiglione-Gertsch M, Gelber RD, Rabaglio M et al. 2005 A comparison of letrozole and tamoxifen in postmenopausal women with early breast cancer. New England Journal of Medicine 353 2747-2757. (doi:10. 1056/NEJMoa052258)

Tsavachidou D, McDonnell TJ, Wen S, Wang X, Vakar-Lopez F, Pisters LL, Pettaway CA, Wood CG, Do K-A, Thall PF et al. 2009 Selenium and vitamin E: cell type- and intervention-specific tissue effects in prostate cancer. Journal of the National Cancer Institute 101 306-320. (doi:10.1093/ jnci/djn512)

Wabitsch M, Brenner RE, Melzner I, Braun M, Moller P, Heinze E, Debatin KM \& Hauner H 2001 Characterization of a human preadipocyte cell strain with high capacity for adipose differentiation. International Journal of Obesity and Related Metabolic Disorders 25 8-15. (doi:10.1038/sj.ijo.0801520)

Wang L, Bonorden MJ, Li GX, Lee HJ, Hu H, Zhang Y, Liao JD, Cleary MP \& Lu J 2009 Methyl-selenium compounds inhibit prostate carcinogenesis in the transgenic adenocarcinoma of mouse prostate model with survival benefit. Cancer Prevention Research 2 484-495. (doi:10.1158/1940-6207. CAPR-08-0173)

Yang S, Fang Z, Suzuki T, Sasano H, Zhou J, Gurates B, Tamura M, Ferrer K \& Bulun S 2002 Regulation of aromatase P450 expression in endometriotic and endometrial stromal cells by CCAAT/enhancer binding proteins (C/EBPs): decreased C/EBPbeta in endometriosis is associated with overexpression of aromatase. Journal of Clinical Endocrinology and Metabolism 87 2336-2345. (doi:10.1210/jc.87.5.2336)

Zhang J, Wang L, Anderson LB, Witthuhn B, Xu Y \& Lu J 2010 Proteomic profiling of potential molecular targets of methyl-selenium compounds in the transgenic adenocarcinoma of mouse prostate model. Cancer Prevention Research 3 994-1006. (doi:10.1158/1940-6207.CAPR-09-0261)

Zhao Y, Nichols JE, Bulun SE, Mendelson CR \& Simpson ER 1995 Aromatase P450 gene expression in human adipose tissue. Role of a Jak/STAT pathway in regulation of the adipose-specific promoter. Journal of Biological Chemistry 270 16449-16457. (doi:10.1074/jbc.270.27.16449)

Zhao Y, Agarwal VR, Mendelson CR \& Simpson ER 1996a Estrogen biosynthesis proximal to a breast tumor is stimulated by PGE2 via cyclic AMP, leading to activation of promoter II of the CYP19 (aromatase) gene. Endocrinology 137 5739-5742. (doi:10.1210/en.137.12.5739)

Zhao Y, Nichols JE, Valdez R, Mendelson CR \& Simpson ER 19966 Tumor necrosis factor-alpha stimulates aromatase gene expression in human adipose stromal cells through use of an activating protein-1 binding site upstream of promoter 1.4. Molecular Endocrinology 10 1350-1357. (doi:10. 1210/me.10.11.1350)

Zhou J, Gurates B, Yang S, Sebastian S \& Bulun SE 2001 Malignant breast epithelial cells stimulate aromatase expression via promoter II in human adipose fibroblasts: an epithelial-stromal interaction in breast tumors mediated by CCAAT/enhancer binding protein beta. Cancer Research 61 2328-2334.

Received in final form 18 November 2011 Accepted 29 November 2011 Made available online as an Accepted Preprint 29 November 2011 